http://dx.doi.org/10.12775/szhf.2013.026

\author{
PrzemysŁaW Chmielecki
}

\title{
Karol Marks jako tyran - czy na pewno? Humanistyczne elementy w filozofii
}

\author{
Słowo wstępne
}

Karol Marks - jedna osoba, a tak wiele sprzecznych ze sobą skojarzeń. Jedni obarczają go winą za wszelkie zło komunizmu, inni dostrzegają w nim wizjonera czy wręcz ,boga'. Niestety ocena ta często wsparta jest na niepewnych fundamentach, na podstawie wyrwanych z kontekstu chwytliwych haseł typu: „religia jest opium dla ludu” czy też „proletariusze wszystkich krajów łączcie się". Ich nieopatrzne interpretowanie przez komunistycznych dyktatorów stało się wygodnym usprawiedliwieniem dla zbrodni z okresu brutalnych rządów. Jednakże powyższe stanowiska stanowią zaledwie niewielki ułamek możliwych ulokowań $w$ ramach danej tematyki, gdyż „[...] marksizm nie przestał być przedmiotem gorących sporów i jednym z najtrwalszych układów odniesienia poszukiwań w zakresie teorii społeczeństwa”" ${ }^{1}$ W związku $\mathrm{z}$ tym, odpowiedź na postawione w tytule pytanie nie może być ani prosta, ani jednowymiarowa.

Celem niniejszego artykułu jest próba ukazania sylwetki Karola Marksa z perspektywy humanistycznej, by dokonać czegoś w rodzaju schizmy w zakorzenionym stereotypie na jego temat. Oczywiste jest, że praca nie stanowi kompendium wiedzy o Marksie i jego doktrynie - ma ona wyraźnie charakter wycinkowy i szkicowy.

\footnotetext{
${ }^{1}$ J. Szacki, Historia myśli socjologicznej. Wydanie nowe, Warszawa 2002, s. 212.
} 


\section{Marks jako człowiek}

Karol Marks urodził się w 15 maja 1818 roku w Trewirze (Nadrenia, ówczesne Prusy), a zmarł 15 marca 1883 roku w Londynie. Pochodził z zamożnej i religijnej rodziny żydowskiej - obaj dziadkowie byli rabinami, ojciec zaś uznanym prawnikiem. Młody Marks niewątpliwie wychowywał się w duchu liberalnym. W edukacji odznaczał się pilnością i dokładnością. Studiował prawo i filozofię na uniwersytecie w Bonn, później w Berlinie. W 1841 roku $\mathrm{w}$ trybie zaocznym obronił doktorat $\mathrm{z}$ filozofii na uniwersytecie $\mathrm{w}$ Jenie (niem. Die Differenz der demokritischen und epikureischen Naturphilosophie; Różnica między demokrytejską a epikurejską filozofią przyrody), jednak ze względu na przynależność do heglowskiej lewicy pracy akademickiej nie mógł podjąć. Zaangażował się wówczas bez mała w pracę dziennikarską dla skrajnie lewicowej gazety Rheinische Zeitung. Po zawieszeniu gazety udał się do Paryża, by tam redagować w Deutsch-Französischen Jahrbücher. Wyrzucony z Francji w 1945 roku udaje się do Brukseli, później do Kolonii, by ostatecznie osiąść w Londynie².

Stereotyp Karola Marksa utożsamia go przede wszystkim z teoretykiem systemu komunistycznego. Faktem jest, że w XX wieku marksizm stanowił koło napędowe wielu dla krajów komunistycznych, ze Związkiem Radzieckim na czele. Ambicja filozofii Marksa wykraczała bowiem poza myślowe spekulacje, inspirując do czynów. Jednakże, jak podkreśla Barbara Magdalena Dworak,

[...] obarczanie Marksa bezpośrednią winą za zło totalitaryzmów i zbrodnie popełnione pod szyldem marksizmu zdaje się tu nazbyt prymitywne, to jednak nieodpowiedzialnością byłoby też nie zauważyć, że jego idee inspirowały działania Lenina i Stalina ${ }^{3}$.

Należy zatem jednoznacznie oddzielić marksowską teorię od zbrodni popełnianych „w imię komunistycznej filozofii marksistowskiej”. Fakt ten podkreśla również uznany autorytet w dziedzinie socjologii, Jerzy Szacki, pisząc:

${ }^{2}$ R. T. Ptaszek, Marks Karol, [hasło w:] Powszechna encyklopedia filozofii, t. 6, Lublin 2005, s. 851; F. Copleston, Historia filozofii, t. 7: Od Fichtego do Nietzschego, Warszawa 1995, s. 309; W. Tyburski, A. Wachowiak, R. Wiśniewski, Historia filozofii i etyki. Źródła i komentarze, Toruń 1997, s. 445; F. Wheen, Karol Marks. Biografia, Warszawa 2005, s. 9-33; J. Didier, Słownik filozofii, Katowice 2006, s. 223.

${ }^{3}$ B. M. Dworak, Systemy totalitarne we wspótczesnej myśli filozoficznej i społecznej, Kraków 2011, s. 31. 
„Na dorobek ten [Karola Marksa - przyp. P. Ch.] patrzy się więc dziś często głównie przez pryzmat jego politycznych implikacji, nie interesując się zbytnio ani tym, czym marksizm był na tle swoich czasów, ani tym, czym jako teoria społeczeństwa różni się od ideologii, która - w sposób uprawniony czy też nie - powoływała się bez ustanku na jego ustalenia"4. Nie wolno jednak zapominać, że poza działalnością polityczną Karol Marks zajmował się ponadto filozofią, ekonomią, historią, socjologią oraz literaturą i poezją. W ciągu życia spisał większość swoich poglądów, które z czasem doczekały się opasłych, wielotomowych wydań. Samodzielnie dokonywał translacji na rozmaite języki (niektóre źródła podają, że władał dziewięcioma językami obcymi). Najbardziej znanym dziełem Marksa jest Kapitał. Za życia autora ukazał się jedynie pierwszy tom jego życiowego dzieła (1867). Kolejne dwa zebrał i opracował Fryderyk Engels, wydając w 1885 r. tom drugi, zaś dziewięć lat później tom trzeci. W poczet innych istotnych dzieł włączyć należy również: Przyczynek do krytyki heglowskiej filozofii prawa (1843), Rękopisy ekonomiczno-filozoficzne (1844), Tezy o Feuerbachu (1845), Manifest Partii Komunistycznej (1848), Walki klasowe we Francji (1850), 18 brumaire'a Ludwika Bonaparte (1852), Płaca, cena i zysk (1865), Wojna domowa we Francji (1871), W obronie Polski (1875; wraz z Engelsem). Problematyczne jest jednakże odróżnienie czystej myśli Marksa od ideologicznie wzmocnionych opublikowanych prac, rzekomo jego autorstwa. Poddane cenzurze prace miały przyjąć postać zbioru dogmatów (niż marksowskich hipotez) przysposabiających treść do roli ideologii ruchu komunistycznego ${ }^{5}$.

Warto jednakże spojrzeć na Karola Marksa z zupełnie innej perspektywy. Można by wręcz powiedzieć, że stanowi on przykład zorientowanego humanistycznie naukowca-pasjonata, który całe swoje życie złożył w ofierze innym ludziom, wyznaczając sobie za cel walkę z nierównościami i niesprawiedliwością społeczną. Jego poświęcenie, całe dnie i noce spędzone na analizie publikacji książkowych, a także, ponadprzeciętna inteligencja przyczyniły się do zmiany spojrzenia wielu ludzi na ekonomię, historię, politologię, filozofię czy socjologię. Słusznie zatem podaje Francis Wheen w biografii Marksa:

Od czasów Chrystusa żaden inny nieznany szerzej biedak nie wzbudził uwielbienia na tak ogromną, ogólnoświatową skalę - nigdy też wcześniej błędna interpretacja czyichś słów nie okazała się tak katastrofalna w skutkach ${ }^{6}$.

\footnotetext{
${ }^{4}$ J. Szacki, Historia myśli, s. 212.

5 Tamże.

${ }^{6}$ F. Wheen, Karol Marks. Biografia, s. 9.
} 


\section{Podbudowa filozoficzna}

Naukową twórczość Marksa trudno jest zakwalifikować do określonego typu. $Z$ pewnością nie był on typem pisarza akademickiego, zdecydowanie bliżej było mu zaś do renesansowego humanisty, gdyż myśl jego nigdy nie była skierowana do jednostek, lecz dotykała szeroko zakrojonego problemu społecznego ${ }^{7}$. Wybitny znawca i analityk filozofii marksistowskiej, Leszek Kołakowski, zaznacza, że marksizm stanowi pewną syntezę filozoficzno-antropologicznych założeń, doktryny socjalistycznej oraz analizy ekonomicznej, czerpiąc swoje źródła w niemieckiej dialektyce, francuskiej myśli socjalistycznej, a także angielskiej ekonomii politycznej ${ }^{8}$. Spory wpływ na poglądy młodego Marksa wywarła niemiecka dialektyka Georga Wilhelma Friedricha Hegla. Nie przejmuje on jednak bezrefleksyjnie założeń swojego mistrza, ponieważ odrzuca pogląd, że człowiek jest jedynie wtórną formą państwa, twierdząc, iż:

demokracja bierze za punkt wyjścia człowieka i zmienia państwo w zobiektywizowanego człowieka [...] tak samo nie ustrój państwowy stwarza naród lecz naród stwarza ustrój państwowy9.

Staje on zatem w obronie jednostki ludzkiej, wyraźnie podkreślając, że podmiotem jest rodzina i społeczeństwo obywatelskie, nie zaś państwo ${ }^{10}$. Postuluje także emancypację człowieka, dzięki której nastąpić powinna przemiana zbiorowego, gatunkowego charakteru życia ludzkiego w życie rzeczywiste, w rezultacie czego, samo społeczeństwo powinno nabrać kolektywnego charakteru i zbiegać się z życiem państwowym ${ }^{11}$. Człowiek bowiem istnieje „nie jako wytwór historii, lecz jako punkt wyjścia historii”"12.

Punktem zwrotnym w filozofii Marksa było opracowanie autorskiej koncepcji, zwanej „materialistycznym pojmowaniem dziejów”. Jej podstawę stanowiło założenie, że otaczająca rzeczywistość jest natury materialnej, a obowiązujące prawa dotyczą nie sfery duchowej, lecz skierowane są na materię,

\footnotetext{
${ }^{7}$ L. Kołakowski, Główne nurty marksizmu, t. 1, Warszawa 2009, s. 16.

8 Tamże, s. 16.

9 Tamże, s. 148.

${ }^{10}$ F. Copleston, Historia filozofii, t. VII: Od Fichtego do Nietzschego, Warszawa 1995, s. 310.

${ }^{11}$ L. Kołakowski, Główne nurty, s. 151.

${ }^{12}$ K. Marks, Wprowadzenie (Do krytyki ekonomii politycznej), [w:] K. Marks, Dzieła wybrane. Człowiek i socjalizm, Warszawa 1979, s. 507.
} 
życie społeczne ${ }^{13}$. Tym, co różniło dialektykę Marksa i Hegla był fakt, że ruch dialektyczny odnosił się głównie do rzeczywistości (przyrody i dziejów), nie zaś do myśli, będącej jedynie odbiciem procesu rzeczywistości. $Z$ tego powodu dialektyka marksistowska określana była mianem dialektyki poheglowskiej ${ }^{14}$. Materializm historyczny odwoływał się nie tylko do myśli Hegla. Marks czerpał również z twórczości Ludwiga Feuerbacha, sądząc że materia jest pierwotna względem umysłu, gdyż stawanie się człowiekiem jest niczym innym jak uprzedmiotowieniem się przez odróżnienie z przyrody ${ }^{15}$. Głosił ponadto, że przyroda istnieje dla istoty ludzkiej tylko i wyłącznie jako pole do przekształceń, gdyż człowiek jako istota ekonomiczna, samodzielnie przekształca naturę, by zaspokoić własne potrzeby ${ }^{16}$.

Czerpiąc z kantowskiej idei aktywizmu, Marks wierzył, że bieg dziejów można kształtować w sposób rozumny i świadomy na podstawie odkrytych praw rozwoju społecznego, co miało stać się obowiązkiem nowoczesnego filozofa ${ }^{17}$. Odchodził od koncepcji, że filozofia służy tylko zrozumieniu świata i że można zawierzyć pracy idei czy rozumu. Sama krytyka tradycyjnych idei $i$ istniejących instytucji nie spowoduje ich zmiany ${ }^{18}$. Wyraźnie zaznaczał to stanowisko, pisząc: „filozofowie rozmaicie tylko interpretowali świat; idzie jednak o to, aby go zmienić" ${ }^{19}$. Niejako receptą na to jest przezwyciężenie filozofii przez jej urzeczywistnienie. Oznacza to nic innego, jak porzucenie teoretycznej płaszczyzny i przeniknięcie do mas społecznych pod postacią rewolucji najbardziej uciemiężonej klasy. Jako sposób wyzwolenia proletariatu i ogółu społeczeństwa Marks proponuje odrzucenie własności prywatnej, w konsekwencji czego nastąpi wyzbycie się egoizmu i niesprawiedliwości społecznych ${ }^{20}$.

Podsumowując rozważania dotyczące filozoficznych korzeni marksizmu, warto odnieść się ponownie do wypowiedzi Leszka Kołakowskigo, zdaniem którego, w myśli Marksa zauważalne są trzy główne motywy: romantyczny, prometejsko-faustyczny, a także oświeceniowy, deterministyczny i racjonalistyczny. Pierwszy z nich objawia się jawnym atakiem na społeczeństwo indu-

\footnotetext{
${ }^{13}$ W. Tyburski i in., Historia filozofii, s. 445.

${ }^{14}$ F. Copleston, Historia, s. 319.

${ }^{15}$ Tamże.

16 Tamże, s. 321.

${ }^{17}$ W. Tyburski i in., Historia filozofii, s. 446.

${ }^{18}$ F. Copleston, Historia, s. 309.

${ }^{19}$ K. Marks, Tezy o Feuerbachu, [w:] K. Marks, Dzieła wybrane, s. 228.

${ }^{20}$ F. Copleston, Historia, s. 311.
} 
strialne, gdzie tradycyjne międzyludzkie więzi i lojalność tracą na znaczeniu na rzecz zamiany jednostki w reprezentację bezosobowych sił kolektywnych będących nosicielami pieniądza i instytucji. W tej sytuacji zanikowi ulega ludzka osobowość a także wzajemna komunikacja, dzięki której istniały wspólnoty. Typowym elementem obecnym w twórczości Marksa, a zarazem charakterystycznym dla ogólnie pojmowanej filozofii romantycznej i preromantycznej, było przeciwstawienie sobie „wspólnoty organicznej” jako żywego organu społecznego $\mathrm{z}$,mechanicznym agregatem”, gdzie tylko negatywna więź utrzymuje społeczeństwo w równowadze. Marks wyraźnie atakuje te cechy społeczeństwa industrialnego wywołujące niszczące skutki. Jednakże utopia marksistowskiego rozumowania objawia się w wierze, że w przyszłym świecie wszelka mediacja między jednostką a ludzkością zostanie zniesiona, że machiny stojące pomiędzy pojedynczym człowiekiem a całym społeczeństwem znikną, że przestaną obowiązywać podziały państwowe, prawne czy narodowe, a także że jednostka w sposób dobrowolny połączy się ze wspólnotą, bez przymusu, bez konfliktu. Kolejny motyw, prometejsko-faustyczny, stanowi odwołanie do charakterystycznych dla humanizmu tendencji, takich jak wiara w nieograniczone możliwości człowieka jako kreatora samego siebie, ujmowanie historii jako procesu samotworzenia przez pracę, pogarda wobec tradycji i kultu przodków czy też przekonanie, że człowiek dnia jutrzejszego swoją „poezję” czerpać powinien z przyszłości, nie zaś z dziejów minionych. Marks głęboko wierzył, że kolektywny Prometeusz, jak określał proletariat, w swojej jaśniejącej blaskiem rewolucji raz na zawsze zniesie odwieczną sprzeczność miedzy interesami jednostki a interesami gatunku. Nie uznawał ponadto fundamentalnej skończoności człowieka, lecz raczej fakt, iż istnienie człowieka jest w pełni określone przez jego społeczny byt. Zdaniem Marksa zło i cierpienie są dźwigniami przyszłego wyzwolenia, gdyż ani nie mają własnego sensu ani też nie są koniecznymi składnikami życia, a są tylko i wyłącznie faktami społecznymi. Ostatnim motywem myśli marksistowskiej jest motyw oświeceniowym deterministyczny i racjonalistyczny. Najogólniej rzecz ujmując, stanowi on swoistą granicę zapędów prometeistycznych, dyktując myśli naukowej konieczność zarzucenia uprzedzeń, sentymentów oraz wartościowania ${ }^{21}$.

${ }^{21}$ Por. L. Kołakowski, Główne nurty, s. 296-504. 


\section{Teoria ekonomiczna}

Kamieniem milowym w historii była innowacyjna teoria ekonomiczna wyłożona przez Karola Marksa w pierwszym tomie Kapitału. Dzieło Marksa ma charakter dogłębnej, a zarazem żywiołowej analizy systemu kapitalistycznego jako bezlitosnej względem człowieka machiny czyniącej go więźniem kultu bezosobowego kapitału i towaru. Na poziomie struktur społecznych Marks zauważał, że: „społeczeństwo nie składa się z jednostek, lecz wyraża sumę więzi i stosunków, w których jednostki te pozostają względem siebie"22, a „nowoczesne społeczeństwo burżuazyjne, które się wyłoniło z upadającego społeczeństwa feudalnego, nie zniosło przeciwieństw klasowych. Stworzyło tylko w miejsce dawnych nowe klasy, nowe warunki ucisku, nowe formy walki"23. Wyraźnie zrodziło to podział społeczeństwa na dwie biegunowe klasy: posiadaczy środków produkcji i robotników sprzedających swoją pracę. Własność środków produkcji stawiała jednych ponad drugimi, ułatwiając tym samym wyzysk. Niewątpliwie z tego powodu stale dochodziło do zaogniania coraz to nowych konfliktów ${ }^{24}$.

Ważne jest pojęcie towaru, który Marks rozumiał dosyć trywialnie, jako przedmiot zewnętrzny, który przez swoje własności zaspokaja potrzeby człowieka, przy czym charakter potrzeb nie ma żadnego znaczenia w tej kwestii ${ }^{25}$. Marks wskazuje, że towar charakteryzują dwie wartości: użytkowa i wymienna. Użyteczność przedmiotu dotyczy jego przeznaczenia i praktycznego wykorzystania. Nie jest ona jednak oderwana od „ciała towaru”, czyli substancji ją tworzącej, jak np. żelazo czy pszenica. Zatem samo „ciało towaru” stanowi wartość użytkową, czyli swego rodzaju dobro. Z kolei wartość wymienna odzwierciedla przelicznik jednego towaru względem innego. Jest to nic innego jak pewna proporcja czy stosunek ilościowy, za pomocą których wyraża się wartość pewnej ilości towaru $x$, stosując jako miarę towar $y$. Oczywiście wartość wymienna podlega ciągłej zmienności zależnie od czasu i miejsca ${ }^{26}$.

Każdy towar jest ponadto produktem pracy. Jednakże jego wartość powinna zawierać w sobie nie tylko ilość pracy niezbędnej do wykonania przedmiotu, lecz także pracy związanej z wytworzeniem narzędzi i przemysłowych maszyn oraz pracy koniecznej do pozyskania surowców niezbędnych do pro-

\footnotetext{
${ }^{22}$ K. Marks, Zarys krytyki ekonomii politycznej, Warszawa 1986, s. 192.

${ }^{23}$ K. Marks, F. Engels, Manifest partii komunistycznej, [w:] K. Marks, Dzieła wybrane, s. 353.

${ }^{24}$ M. Belka (red.), Ekonomia stosowana, Warszawa 1997, s. 14.

${ }^{25}$ K. Marks, Kapitat, t. 1 (cz. 1), Warszawa 2010, s. 59.

${ }^{26}$ Tamże, s. 60-61.
} 
dukcji. Karol Marks dodaje bezzwłocznie, że mowa tu o „społecznie niezbędnym czasie pracy", gdyż w przypadku leniwych bądź niezdarnych robotników można by błędnie sądzić, że wartość owego towaru jest wyższa, przez znacznie dłuższy czas pracy ${ }^{27}$. Nie było w tym jednak nic innowacyjnego względem klasycznej ekonomii reprezentowanej chociażby przez Adama Smitha czy Davida Ricardo. Nowością było rozszerzenie owej dychotomii własności towaru na pracę. Wartość użytkowa pracy odnosi się do „pracy użytecznej”, czyli specjalnej i celowej działalności produkcyjnej przystosowującej poszczególne materiały dane przez przyrodę do określonych potrzeb ludzkich ${ }^{28}$. Praca w tym wymiarze jest warunkiem istnienia człowieka, istniejącą ponad wszelkimi ustrojami politycznymi, przyrodzoną koniecznością umożliwiającą wymianę materii na linii człowiek-przyroda, czyli umożliwiającą ludzką egzystencję ${ }^{29}$.

Kolejnym problemem, który poruszał Marks, jest kwestia pominięcia znaczenia pracy ludzkiej w wytwarzaniu towarów. Przedstawił on problem obrazowo, mówiąc, że „[...] siły materialne obdarzone zostają życiem duchowym, a życie ludzkie [zostaje - P. Ch.] przytępione i sprowadzone do poziomu sił materialnych" ${ }^{30}$. Mówi tu wręcz o tyranii robotników i zawiesza sąd nad tym, dlaczego robotnik nie otrzymuje całej wartości wytworzonego produktu, skoro sam go stworzył. W kwestii wymiany handlowej Marks przytacza dwie formuły cyrkulacji towarów: sprzedaż w celu kupna (T-P-T) i kupno w celu sprzedaży $(\mathrm{P}-\mathrm{T}-\mathrm{P})^{31}{ }^{32}$. W przypadku pierwszym pieniądz zostaje wydany, w drugim zaś jest jedynie „zaliczkowany”, gdyż znalazł się w cyrkulacyjnym obiegu wyłącznie $\mathrm{z}$ chytrego zamiaru otrzymania go z powrotem ${ }^{33}$. Forma ta wydaje się pozbawiona treści i tautologiczna, gdyż zarówno $\mathrm{P}$ początkowe $\left(\mathrm{P}_{\mathrm{p}}\right)$, jak i $\mathrm{P}$ końcowe $\left(\mathrm{P}_{\mathrm{k}}\right)$ obrazują tę samą jakość. Często jednak zdarza się, że $\mathrm{P}_{\mathrm{p}} \neq \mathrm{P}_{\mathrm{k}}$, tylko $\mathrm{P}_{\mathrm{k}}=\mathrm{P}_{\mathrm{p}}+\Delta \mathrm{P}$. Zatem $\mathrm{P}_{\mathrm{k}}$ równa się początkowej wartości powiększonej o pewien przyrost (nazywany przez Marksa „wartością dodatkową"). Taką formułę Marks proponuje przedstawiać jako: P-T-P’. Oczywiście możliwy jest również wariant T-P-T', lecz określenie różnicy wartości towaru jest trudne

\footnotetext{
27 Tamże, s. 65.

${ }^{28}$ Tamże, s. 65, 70-71.

${ }^{29}$ Tamże, s. 264.

${ }^{30}$ K. Marks, Przemówienie wygłoszone na obchodzie rocznicy gazety „The People’s Paper”, [w:]

K. Marks, F. Engels, Dzieła, t. 1, Warszawa 1949, s. 333-334.

${ }^{31}$ K. Marks, Kapitat, t. 1 (cz. 1), Warszawa 2010, s. 214.

${ }^{32}$ Symbol $\mathrm{T}$ oznacza towar, a $\mathrm{P}$ pieniądz.

${ }^{33}$ Tamże, s. 216.
} 
do ustalenia. Proces zamiany P w P' Marks określa mianem przekształcenia pieniądza w kapitał. Ruch ten, jego zdaniem, nie ma granic ${ }^{34}$. Wymiana towarów ma $z$ swej istoty charakter zamknięty, nie wymaga bowiem włączania dodatkowych stosunków zależności. Zatem „[...] siła robocza może się zjawić na rynku jako towar tylko wówczas i dlatego, że jej posiadacz, człowiek którego siłę roboczą ona stanowi, wystawia ją na sprzedaż, czyli sprzedaje jako towar" ${ }^{35}$. Praca robotnika zostaje rozbita na dwie części: niezbędny czas pracy i czas pracy dodatkowej. Pierwszy typ stanowi pracę konieczną dzięki której robotnik otrzymuje zapłatę, drugi zaś jedynie powiela zysk posiadacza. W tej sytuacji Marks ucieka się do wymownego porównania, że „[...] społeczeństwo oparte na pracy niewolniczej i społeczeństwo oparte na pracy najemnej, różnią się od siebie tylko formą, w jakiej ta praca dodatkowa jest wyciskana $\mathrm{z}$ bezpośredniego wytwórcy, z robotnika" ${ }^{36}$. Autor krytycznie odnosi do jawnej niesprawiedliwości w zaistniałych relacjach wykazując, że „gdy kapitalista osiąga zysk, robotnik niekoniecznie musi zyskiwać, natomiast straty dzieli on z kapitalistą nieuchronnie" ${ }^{37}$. Marks kończy pierwszy tom Kapitału smutną konkluzją, że „[...] kapitalistyczny sposób produkcji i akumulacji, a więc też kapitalistyczna własność prywatna, zakłada unicestwienie prywatnej własności opartej na własnej pracy, to znaczy wywłaszczenie robotnika"38.

W kwestii formalnej można wysunąć poważne wątpliwości co do naukowego statusu teorii ekonomicznej Karola Marksa. Jego „[...] koncepcja nie została jednoznacznie sformułowana, stała się punktem wyjścia dwóch różnych de facto teorii socjologicznych podawanych przez swoich zwolenników za rdzennie marksistowskie [...]" ${ }^{39}$ - brak jej zatem naukowej ścisłości i jednoznaczności. Kolejne zarzuty odnoszą się do niedostatecznego zweryfikowania postawionych hipotez, ograniczenia wyłącznie do wąskiego kręgu kulturowego i przedwczesne uznanie wysnutej refleksji jako uniwersalnego prawa $^{40}$.

\footnotetext{
34 Tamże, s. 219-221.

35 Tamże, s. 242.

36 Tamże, s. 310.

${ }^{37}$ K. Marks, Rękopisy ekonomiczno-filozoficzne z 1844 roku, [w:] K. Marks, Dzieła wybrane, s. 59.

${ }^{38}$ K. Marks, Kapitat, t. 1 (cz. 2), Warszawa 2010, s. 660.

${ }^{39}$ J. Szacki, Historia myśli, s. 221.

${ }^{40}$ Tamże, s. 223.
} 


\section{Słowo podsumowujące}

Postać Karola Marksa w społecznej recepcji często jest ograniczona wyłącznie do ideologii komunizmu, ze szczególnym podkreśleniem jej negatywnych następstw. Dogmatyzm marksistów objawiał się w „[...] przekonaniu, że w dziele mistrza zawierają się przynajmniej implicite odpowiedzi na wszelkie możliwe pytania [...] traktowaniu marksizmu jako ponadczasowej prawdy, którą wystarczy w razie potrzeby odsłonić" ${ }^{41}$. Taki obraz Marksa i jego twórczości dopełnia traktowanie go niczym proroka i nieuprawnione manipulowanie treścią jego prac. Nie trudno zatem o opinię lokującą Marksa w szeregu z Leninem, Stalinem, Ir Senem, Mao, Castro, etc. Warto jednak $\mathrm{w}$ tym momencie postawić pytanie: czy miejsce w tym rzędzie, gdzie „[...] stalinowska ideologia, której zadaniem było lub jest usprawiedliwić stalinowski system organizacji społecznej, była prawomocną interpretacją marksistowskiej filozofii dziejów" jest w pełni zasadne? ${ }^{42}$.

Podkreślić trzeba raz jeszcze, że niniejsza praca nie jest obroną ani pochwałą systemu socjalistycznego, ani usprawiedliwieniem dla rozlicznych krzywd zaistniałych podczas dyktatur. Celem była próba ukazania pierwiastka humanistycznego w myśli Karola Marksa oraz demistyfikacja stereotypów splecionych $\mathrm{z}$ jego osobą. Owe pozytywne elementy objawiają się w trosce o człowieka, który zajmuje ważne miejsce w całym systemie. Autor Kapitału stoi na stanowisku, że najdrastyczniejszym skutkiem kapitalizmu dla jednostki ludzkiej jest odarcie relacji międzyosobowych z czynnika personalnego. Perspektywa Karola Marksa jawnie sprzeciwia się owym mechanistycznym stosunkom interpersonalnym, gdzie przestała liczyć się moralność oparta na ludzkich wartościach.

\footnotetext{
${ }^{41}$ Tamże, s. 213.

${ }^{42}$ L. Kołakowski, Czy diabeł może być zbawiony? I 27 innych kazań, Kraków 2006, s. 347.
} 


\section{Abstract \\ Karl Marx a Tyrant - beyond a Doubt? Humanistic Elements in the Philosophy}

Keywords: Karl Marx, Marxism, economic theory, humanism

This article is an attempt to show Karl Marx from the humanistic perspective in order to prove that it is unauthorized to blame him for all the evil of totalitarianism. The semantic content of the presented material includes three key areas. The first figure refers to Karl Marx, his personal characteristics and activity. Secondly, a question of philosophical foundations on which the thought of Marx is set. The third aspect of the problem concerns his economic theory. All these planes are explored through the prism of Marx's humanism. The article is summarised by a short reflection which denudes errors in Marx is dogmatism and reflect son the pertinence of setting Marx in a series of dictator criminals. 